\title{
Ten years of implementing Australia's Oceans Policy: From an integrated approach to an environmental policy focus
}

\author{
Joanna Vince*
}

The release of Australia's Oceans Policy in 1998 was recognised in Australia and internationally as a milestone in marine resource management. The policy outlined a new, national approach for ecosystem-based ocean management. It also sought to integrate sectoral and jurisdictional interests through the establishment of new institutions and the adoption of new implementation methods (such as Regional Marine Plans). In 2003, the present writer's review in Maritime Studies reflected on five years of policy implementation and the struggle to achieve full integration. This paper follows on from that review and analyses how, after ten years of implementation, the original focus of the policy implementation process has changed, reflecting an unfortunate lack of integration and institutional restructuring.

\section{Introduction}

The year 2008 marks ten years since the release of Australia's Oceans Policy ('Oceans Policy'), an oceans governance framework that embraces ecosystem-based and integrated approaches to policy implementation. The Oceans Policy was viewed as a milestone in marine resource management because it was a 'world first' national policy that demonstrated a commitment to the 1982 Law of the Sea Convention (LOSC) and the United Nations Conference on the Environment and Development's (UNCED) Agenda 21. Parties to LOSC have

sovereign rights for the purpose of exploring and exploiting, conserving and managing the natural resources, whether living or nonliving, of the waters superjacent to the sea-bed and of the sea-bed and its subsoil within their Exclusive Economic Zones (EEZs). ${ }^{2}$ They are also obligated to protect and preserve the marine environment within their EEZs. $^{3}$ Agenda 21 establishes three key principles aimed at sustainable development 'integrated' (Chapter 17), 'precautionary' (Principle 15 Rio Declaration) and 'anticipatory' actions. Chapter 17 deals with all aspects of marine and coastal environmental management through 137 recommendations including that coastal States

commit themselves to integrated management and sustainable development of coastal areas and the marine environment under their national jurisdiction. ${ }^{4}$

The Australian Conservation Foundation estimated that Australia has over one hundred statutes, regulations and policies that address aspects of the management of its coasts and oceans. $^{5}$ Australia's oceans regime has been fraught with jurisdictional and sectoral conflict since federation. ${ }^{6}$ Initially, the Australian Government's aim was to develop a policy that would integrate sectoral interests (such as fishing, oil extraction and petroleum mining) with each other and with the jurisdictional interests and responsibilities of the Australian Government and state/territory governments. By the time the Oceans Policy was released in December 1998, it was clear that this was a Commonwealth government initiative. Although different state-based and private sectors were involved in the development of the policy, full sectoral integration had yet to be achieved. $^{7}$

This paper examines the implementation of this 'new' policy. It examines the first official

\footnotetext{
* Dr Joanna Vince is a Lecturer in the School of Government at the University of Tasmania. Email: Joanna.Vince@utas.edu.au.
} 
policy review (known as the 'TFG review' (below)) that resulted in institutional restructuring. It begins with a recap of the first five years of implementation and then continues where the present writer's 2003 review finished. ${ }^{8}$ The paper then briefly examines the debate to give legislative backing to the Oceans Policy, such as in an Oceans Act. It then discusses the environmental focus of Bioregional Marine Plans. It concludes with an overview of recent directions for oceans management in Australia.

\section{A recap of the first five years of Oceans Policy implementation}

The years preceding the release of the Oceans Policy reflected an optimistic period of policy development. In December 1995, Prime Minister Keating announced the development of an 'integrated oceans strategy', however, little progress was achieved as the federal election dominated the political agenda. In March 1996, the then newly elected Howard government announced that it would continue the development of an oceans policy with the intention of it being an 'environmental protection policy'. The Oceans Policy was intended to set up a framework for full integration across sectors and jurisdictions. State/Northern Territory and other non-governmental and industry stakeholder involvement was encouraged during this period. The states 'reacted positively' to consultation papers ${ }^{10}$ at the time, although they were 'concerned with the [Oceans Policy's] institutional arrangements, financial commitments and obligations." ${ }^{11}$ Stakeholders (such as various interest groups, academics, Aboriginal and Torres Strait Islanders) were represented in the Ministerial Advisory Group on Oceans Policy (MAGOP) (established in 1997) and non-governmental organisations (NGOs) ${ }^{12}$ were asked by the Australian Government to assist with the consultation process. It was unusual for the Australian Government to turn to NGOs during policy consultation and this indicated that a 'bottom-up' approach to implementation rather than a 'top-down' approach was being considered. ${ }^{13}$ The bottom-up approach included stakeholder consultations that were a key element in policy development. Nevertheless, the bottom-up approach was not without its critics and was later recognised as one reason why the implementation of the Oceans Policy was delayed. ${ }^{14}$

The development of the Oceans Policy aimed to ensure its release during 1998, the International Year of the Ocean. By September of that year, the Australian Government was committed to developing the policy and the states were excluded from this part of the process, despite their involvement during early policy development. Sectoral interests continued to be represented through the relevant Australian Government agencies and MAGOP. The policy decisions during the period up to the release of the Oceans Policy documents demonstrate the demise of jurisdictional integration. They also mark the beginning of the Australian Government's change from a bottom-up approach to a centralist approach to policy implementation from the 'top-down'.

The Australian Government released the Oceans Policy on 23 December 1998 in two volumes: Australia's Oceans Policy, and Specific Sectoral Measures. ${ }^{15}$ The policy reveals that

Regional Marine Plans (RMPs) are the core method of implementing [the Oceans Policy] and all Australian Government agencies are bound to those plans. ${ }^{16}$

Although the States were left out of the final development stages of the policy, the then federal environment minister, Senator Robert Hill, stated in the Foreword to the Oceans Policy that

implementing a national oceans policy will need better coordination between the national, state and territory governments in integrating planning and management to ensure that jurisdictional boundaries do not hinder effective management. ${ }^{17}$

The two documents outlined 390 commitments and a range of initiatives and actions.

The most innovative and challenging elements of the Oceans Policy were the new institutional arrangements established to implement the policy through RMPs. Senator Hill emphasised the 'whole of government approach' to implementing the policy. ${ }^{18}$ The new institutions included the National Oceans Ministerial Board, 
National Oceans Office (NOO), Regional Marine Plan Steering Committees and the National Oceans Advisory Group (NOAG). ${ }^{19}$ The NOO was given primary responsibility for development of the RMPs and was envisaged 'to be housed in Environment Australia' ${ }^{20}$ but was later designated as an Executive Agency under the Public Service Act 1999 (Cth) that came into effect in early December $1999 .{ }^{21}$ This meant that the Director of the NOO reported directly to the then Minister for Environment and Heritage, and, through the Minister, to the National Oceans Ministerial Board.

Intergovernmental dimensions of the Oceans Policy process were initially managed through the Australian and New Zealand Conservation Council (ANZECC). ANZECC was replaced in 2001 by the Natural Resource Management Ministerial Council (NRMMC). The NRMMC's functions include developing

policies and strategies for national approaches to the conservation, sustainable use and management of Australia's land, water, vegetation and biological resources,

and monitoring and evaluating 'outcomes of these policies, strategies and programs and the health of the nation's natural resources'. ${ }^{22}$

The 2003 review examined the development of the first RMP to be implemented in the South East region of Australia. It was argued in that review that the development of the South East Regional Marine Plan took much longer than anticipated. A year following the release of the Oceans Policy, only three out of the five key institutions were established; the implementation of the RMP had only been drafted and not finalised; and the commitment to hold the National Oceans Forum in December 1999 was reorganised for April 2000. ${ }^{23}$

The development of the South East Regional Marine Planning (SERMP) process comprised four phases. These were: the scoping or definition of the plan; determining the economic, social, environmental and cultural characteristics of the region via assessments; developing potential options; and analysing those options in order to implement the plan. ${ }^{24}$ A South East States Consultative Working Group was established during the assessment phase, ${ }^{25}$ although no formal state agreements resulted from this development. The formation of this working group

increased informal state communication...in an 'open environment' and it has been interesting for those involved to 'see what works and what doesn't. ${ }^{26}$

\section{Review of the Oceans Policy}

In August 2002, a formal review of the Oceans Policy was commissioned. This was two years before the finalisation of the first RMP. TFG International (a consultancy firm) completed this review. The TFG Review addressed three themes: progress with the implementation of the policy, including progress with regional marine planning; value for money of expended funding; and effectiveness of institutional/governance arrangements in supporting and implementing the policy. ${ }^{27}$

The TFG Review stated that

nothing that has happened since the policy was launched has diminished the importance of the policy. It still represents a major Government priority and a world leading approach. $^{28}$

In relation to progressing key aspects of the Oceans Policy, the review found that of 157 key initiatives in the Oceans Policy 136 (or 87 per cent) were 'completed', 'proceeding' or a 'continuing activity'.

The TFG Review concluded, similar to some commentators at the time, ${ }^{29}$ that that 'the initial implementation schedule for regional marine planning was very ambitious. ${ }^{, 30}$ It identified a number of factors that hindered quicker delivery of the regional marine planning process. These included the:

- decision to establish the NOO as a small Executive Agency located in Hobart;

- complicated nature of regional marine planning;

- lack of a detailed implementation framework in the policy when it was launched;

- required procurement model for securing information (social, economic and marine science); 
- extent of stakeholder consultation required; and

- need to re-engage States and Territories after the policy was launched by the Commonwealth Government. ${ }^{31}$

The TFG Review identified that there was uncertainty about the delivery of the policy and how the implementation process would work, and 'whether it will add value. ${ }^{32}$ It noted the 'major impediments' affecting implementation. These included the lack of jurisdictional integration and lack of agreement over the policy by the states and Northern Territory. It also stressed that

State/Commonwealth co-operation is essential for an effective oceans policy - anything less than a national approach will significantly limit long term effectiveness. Indeed, this is widely acknowledged as being the biggest impediment to achieving the broad objectives of Oceans Policy. ${ }^{33}$

The TFG Review considered ways to improve coordination between the Australian Government and the governments of the states and the Northern Territory. It suggested three models: full national policy (Australian Government, State and Territory agreement); integrated oceans management; and officer level approach (that was the approach at the time). However, it noted that 'complex interactions and interrelationships between legislation is one of the major impediments to implementation. ${ }^{34}$ The lack of a legislative base to the Oceans Policy was also explored in the review and it concluded that the policy approach 'reflects both the complicated interactions and interrelationships between existing legislation and the sensible focus on pursuing a co-operative approach to developing a framework for integrated marine planning., ${ }^{35}$

There was significant focus on the NOO and its role in the review. It found that

[t]he same people who were trying to implement the policy were also doing the work to set the office up ... and slowed the progress on the main task. However it is an unavoidable consequence of the decision to establish an executive agency. ${ }^{36}$

Yet, the TFG Review warned that careful consideration needs to be given to structurally locating it as a separate and distinct office within an existing Department. This could provide it with the stronger management and policy resources that it needs as well as reducing the administrative overheads associated with an Executive Agency. ${ }^{37}$

The review suggested that

some permanent presence in Canberra is highly desirable to provide more effective interaction with Departments, Ministers and their offices and to improve stakeholder engagement

but it acknowledged the difficulties of doing this. It went on to claim that

due regard needs to be given to the implications of fragmenting what is already a small group. One option may be to have the Office located in Canberra, with a small presence in each region while regional marine plans are being developed there. ${ }^{38}$

While the implementation process was proceeding slowly at this time, the TFG Review was timely. It identified key strengths and weaknesses of the implementation process and provided a new direction for the Oceans Policy. This new direction included refocusing the SERMP's overall direction towards 'process' before the final SERMP was released and overhauling the institutional structures.

\section{Continuation of policy implementation}

In October 2002, following the TFG Review, the first formal agreement was signed between Queensland, Northern Territory and the Australian Government dealing with the Northern RMP. ${ }^{39}$ In February 2003 NOO held a workshop in Canberra that was attended by all board agencies. The completion of the SERMP and its future directions were discussed at this meeting. The draft SERMP was released in July 2003 and following the recommendations from the review, it became an 'action plan', focused on process, for implementing the Oceans Policy in the southeast marine region. Also in 2003, a group of Australian environmental NGOs released a report, Oceans Eleven. ${ }^{40}$ The report recommended that ecosystem-based management should remain the basis of Oceans Policy 
implementation and that an Oceans Act should be enacted. ${ }^{41}$ It also claimed that the policy implementation process had 'stalled'. ${ }^{42}$

The SERMP was completed in May 2004. Stakeholders had differing views on what they expected from the final plan. They recognised that there were challenges in developing a 'world's first' plan, and translating the commitments announced in the Oceans Policy into practice. However, some 'disappointment' was expressed with plan, in particular by NGOs on the basis that it did not provide strong commitments in key areas. ${ }^{43}$ This response from environmental groups reflected the differing expectations of stakeholders. ${ }^{44}$ While the implementation of the SERMP has been recognised as 'a process of trial and error for the Commonwealth' 45 it has also evolved over time. The change of focus of the SERMP from 'plan' to 'process' ${ }^{46}$ resulted in an ecosystem-based framework for the making of management and policy decisions at the regional level. It was also a response to concerns expressed by Australian Government agencies over progress in developing the plan. ${ }^{47}$ The implementation of the SERMP has proven to be more complex than first anticipated. However, changes to regional marine planning in 2005 (see below) have provided new directions for the South East region.

\section{Institutional restructuring}

The Australian Government reviewed the institutional framework for the implementation of the Oceans Policy, as suggested by the TFG Report in 2002. Three key changes occurred in the period 2003 to 2007, beginning with the establishment of the Oceans Board of Management and the Science Advisory Group. The Oceans Board of Management

comprises representatives from seven Australian Government departments and agencies relevant to Australia's marine jurisdiction. It was formed to provide highlevel, whole-of-government advice on operational aspects of Australia's Oceans Policy and its central programme of regional marine planning. The Oceans Policy Science Advisory Group, comprising representatives of Australian Government marine science and related agencies, as well as State research institutions and non-government marine science interests was also formed. It is tasked with promoting coordination and information sharing between Government marine science agencies and across the broader Australian marine science community. ${ }^{48}$

The Science Advisory Group is located in Canberra, rather than within or near the NOO in Hobart, also as suggested in the 2002 Review. While this placed it closer to other government agencies in Canberra, the NOO was being divided on a geographical basis. This led to the second key institutional change which occurred in 2004, when the NOO lost its executive agency status and was located within the Marine Division of the then Department of Environment and Heritage. The National Oceans Ministerial Board was also dissolved. However, the cross sectoral approach to policy implementation has continued through the Oceans Board of Management. The third change, in 2007, occurred when the Department of Environment and Heritage was renamed and restructured as the Department of the Environment and Water Resources (DEWR) (since then renamed, see following). The Marine Biodiversity Division within DEWR included four new 'branches': the National Oceans Office Branch; Marine Conservation Branch; Marine Environment Branch; and Natural Resources Policy Branch. The Minister for the Environment has the responsibility for the Division (which includes the NOO Branch) and reports to cabinet on its progress.

The changes to NOO reflected how the federal Howard government came to view the Oceans Policy. The 'oceans' were initially addressed as a singular policy issue. The NOO provided a central point for accessing all things dealing with 'oceans' and reflected the importance of this policy area. By taking away its executive agency status, and making the NOO a branch within the environment department, 'oceans' issues were then located in the broad context of environmental policy. During this time, the argument for oceans legislation was increasing to secure the 'oceans' as a key policy issue (below). 


\section{Legislation versus policy}

The Commonwealth's decision to develop an oceans policy, rather than legislation, has been viewed as a 'safe decision'49 so that new methods could be tested during implementation. In more recent years, advocates have argued that legislative grounding may be needed to give stability to the Oceans Policy. Environmental NGOs are prominent among such advocates (for example, through the Oceans Eleven paper). However, other stakeholders have also developed an interest in this direction such as the National Environmental Law Association (NELA) (below).

The Australian Government largely ignored the need for the development of an Oceans Act, but acknowledged that some legislative grounding was required for the implementation of the Oceans Policy. In October 2005, following the restructuring of the NOO, Senator Ian Campbell, the then Environment Minister, announced that RMPs will be established under section 176 of the Environment Protection and Biodiversity Act 1999 (Cth) (EPBC Act). This has provided a legislative basis and consistency in the implementation of Marine Bioregional Plans (MBPs). MBPs have replaced RMPs and there are key differences between the two plans. First, RMPs focused on environmental and economic aspects of the region and on regional objectives. MBPs, on the other hand, focus mainly on environment issues and outline the 'key conservation issues and priorities in each marine region. ${ }^{50}$ Second, there are now fewer regions identified through MBPs and it is interesting to note that the Antarctic zone is no longer identified as a region.

The original Oceans Policy documents described RMPs as being 'based on large marine ecosystems. ${ }^{51}$ The Oceans Policy stated that RMPs would

propose allocations of ocean resources, delivered principally through existing responsible sectoral management arrangements, using multiple use principles to generate income and employment and to optimise long-term benefits to the community. ${ }^{52}$

This holistic approach to implementing the Oceans Policy, from both environmental and economic aspects, proved difficult to accomplish. By linking the marine plans to the EPBC Act, the environmental focus became a key priority for the marine plans. Nevertheless, the Act still considers economic and other broad social issues. According to sub-section 176(4):

A bioregional plan may include provisions about all or any of the following:

(a) the components of biodiversity, their distribution and conservation status;

(b) important economic and social values;

(ba) heritage values of places;

(c) objectives relating to biodiversity and other values;

(d) priorities, strategies and actions to achieve the objectives;

(e) mechanisms for community involvement in implementing the plan;

(f) measures for monitoring and reviewing the plan.

Under section 176 of the EPBC Act, the Minister for the Environment, Heritage and the Arts must conduct public consultations on draft MBPs and may cooperate with States and Territories if the plan goes beyond Australian Government territory. Marine bioregional plans also provide the platform for the National Representative System of Marine Protected Areas (MPAs). The SERMP and its system of MPAs has been reviewed and adjusted to conform to a MBP. DEWR stressed that the previous work on the SERMP is still valid and

all the objectives contained within the Plan remain relevant and most of the actions have either been implemented or continue to be implemented [through MBPs]. ${ }^{53}$

The former Howard government allocated \$37.7 million over four years in the 2006-7 budget to create MBPs for the whole of Australia. ${ }^{54}$ DEWR noted that the bioregional planning under the EPBC Act

gives new impetus for the implementation of Australia's Oceans Policy by streamlining the planning process and providing greater guidance about marine environment conservation priorities. ${ }^{55}$ 
Current debate centres on the development of an Australian Oceans Act (as is the case in Canada where there is an Oceans $\mathrm{Act}^{56}$ ). The use of section 176 of the EPBC Act has only partially addressed criticism of the lack a legislative base to the ocean policy. In March 2006, the Australian Conservation Foundation (ACF) and NELA released a report entitled Out of the Blue: An Act for Australia's Oceans. ${ }^{57}$ The ACF and NELA hoped that this document would 'kick start' a discussion on Australian oceans governance. The ACF and NELA argued that the EPBC Act can complement an Oceans Act. The report provides a number of recommendations: the development of an Australian Oceans Authority; the signing of an Intergovernmental Agreement on Australia's Oceans by the Australian Government, state and territory governments through the Council of Australian Governments; and increased indigenous community involvement. ${ }^{58}$ Despite these efforts, the former Howard government regarded 'the linking of the Oceans Policy to the EPBC Act as providing a sufficient legislative anchor' ${ }^{59}$ An Oceans Act, whether complementing the EPBC Act or addressing all oceans issues (as in the case of the Oceans Policy) would increase parliamentary debate and scrutiny over decisions regarding Australia's oceans. Debate on oceans issues may even result in a new community consultation process, and support the current Rudd government's view of a more 'participatory democracy' that was demonstrated through the Australia 2020 Summit in April 2008. ${ }^{60}$

\section{An environmental focus for implementation}

In 2003, five years after the release of the Oceans Policy, the present writer concluded that 'it cannot be claimed that there is full integration across sectors and jurisdictions' and that 'the most significant goal for ocean institutions, key stakeholders and interest groups involved in policy implementation will be the continual support of integration across sectors and jurisdictions'. ${ }^{61}$ Policy makers and commentators were optimistic that the RMP process, given time, would result in more integration. In 2006, it was claimed
The SERMP process provides two valuable lessons for the implementation of other RMPs in Australia...First, the aim to reach full integration within a relatively short period of time whilst implementing a new RMP (without an agreed framework) is difficult, if not impossible to accomplish. Commonwealth agencies need to acknowledge that the restraints of Federalism may prevent full integration across sectors and jurisdictions from ever occurring. Second, partial integration in the SERMP has not resulted in policy failure, rather it has increased cohesion, community consultation, stakeholder participation, and communication between sectors and jurisdictions. ${ }^{62}$

The increased 'cohesion' and 'communication' was a significant achievement in Australia's oceans management given the decades of jurisdictional conflict. $^{63}$ However, ten years since its release, the Oceans Policy's focus on integration is no longer a major priority for policy makers. In the process of implementation of any new policy, 'new issues, new requirements new considerations emerge as the process unfolds' ${ }^{64}$ Ecosystem-based management through bioregional marine planning has increased in importance, also reflecting that the policy has gone 'full circle' with its environmental focus. For instance, the original policy documents stated that the NOO was to be located in Environment Australia, then, Senator Hill's push for the NOO to have executive agency status (outside the department) during the early years of implementation reinforced that the Oceans Policy was 'neither solely an environmental protection policy nor solely an economic development policy'. ${ }^{65}$ There was great concern that different sectors and stakeholders would not take part in the development and implementation of RMPs under the Oceans Policy if the lead agency was based in the environment department and had an environmental focus. Arguably, this was the catalyst for increased 'cohesion' and 'communication' during the early years of policy implementation.

Yet, the NOO returned to the environment department and Senator Campbell's efforts to establish a legislative component for bioregional marine planning under the EPBC Act 
reflected that the Australian Government was again interested in an 'environmental' direction for the implementation of the policy. Browne and Wildavsky explain that

[i]mplementation is no longer solely about getting what you once wanted but, instead, it is about what you have since learned to prefer until, of course, you change your mind again. ${ }^{66}$

This does raise the question whether the 'cohesion' and 'communication' across sectors and jurisdictions is as strong as it once was.

\section{Current directions and conclusion}

During the 2007 federal election campaign, political parties announced their positions on various policy issues. The Australian Greens Party (a minor party) was the only party to specifically mention a direction for the Oceans Policy -

The Australian Greens will introduce an Oceans Act that coordinates sustainability of ocean uses through a statutory National Oceans Authority, reporting to the parliament, and enforcing eco-system based regional management plans and targets. ${ }^{67}$

The two major parties, the Australian Labor Party and the Liberal Party (as part of the Coalition) did not address Oceans Policy implementation. The marine component of the Australian Labor Party focused on a Great Barrier Reef 'Rescue Plan'68, while the Coalition Government's election plan focused on fisheries 'Strengthening and Protecting Australia's Fishing Industry'. ${ }^{69}$ This reinforced that 'oceans' as a singular policy issue was no longer a priority for either major party as it was during the 1996 federal election. On 24 November 2007, a new Federal Labor government was elected and nine years of Oceans Policy implementation under the Coalition ended. It is interesting to note that the new government immediately changed the name of the environment department to the Department of the Environment, Water, Heritage and the Arts.

The oceans policy development process demonstrates and reinforces what policy analysts already knew, that 'new' policies are complex and timely. This is indicative of, and an advantage for, implementing 'new' policies. However, Pressman and Wildavsky, who wrote their infamous book on policy implementation, claim 'the advantages of being new are exactly that: being new. They dissipate quickly over time'. ${ }^{70}$ It is not surprising then that the Australian Government made the most of emphasising its 'new', 'world first' policy, and that

when Australian policy makers began developing a new policy and using untried implementation methods they were aware of 'getting it right'. They were conscious that other States would be learning from the [Oceans Policy] process. ${ }^{71}$

Consequently, the Oceans Policy and its institutions and implementation methods have become a source of policy learning and transfer for other countries establishing their oceans policies, such as Canada and New Zealand. ${ }^{72}$ The year 2008 marks a new era for oceans management in Australia and the Oceans Policy will no longer be regarded as a 'new' policy. Pressman and Wildavsky put it best:

youth has gone and middle age has come, hopefully more powerful, certainly more experienced, inevitably less innovative. ${ }^{73}$

The policy decisions up until the release of the Oceans Policy demonstrate the demise of jurisdictional integration, which in the ten years of implementation has never been resolved. The years under the Howard government have demonstrated a commitment to Oceans Policy implementation through innovative methods, namely new institutions delivering ecosystem based management through RMPS. While it is now doubtful that jurisdictional integration is a priority for policy makers, the new emphasis on bioregional marine planning and its legislative grounding appears to be a stable way forward for the continual implementation of the Oceans Policy - although mainly from an environmental perspective. Cohesion between sectors, stakeholders, and jurisdictions, despite the environmental focus, will be an important factor for the continuation of the policy. From this point forth, policy makers, stakeholders and commentators have the opportunity to build on what has already been established by the Oceans Policy process and to re-establish ocean 
and marine issues as a priority for the current and future governments. Pushing the debate for an Oceans Act may be the key to putting 'oceans' back on the government's agenda.

\section{ENDNOTES}

1 See Vince, J.Z. 2003. ‘Australia’s Oceans Policy: Five Years of Integration Across Sectors and Jurisdictions?' Maritime Studies. 133: 1-13; Vince J.Z. 2006. 'The South East Regional Marine Plan: Implementing Australia's Oceans Policy.' Marine Policy. 30: 420430.

2 United Nations, 'Article 56'. Convention on the Law of the Sea, done in Montego Bay, Jamaica, 10 December 1982, in force 16 November 1994, 1833, UNTS 396.

3 United Nations, 'Article 192'. Convention on the Law of the Sea, done in Montego Bay, Jamaica, 10 December 1982, in force 16 November 1994, 1833, UNTS 396.

4 See United Nations. 1992. 'Chapter 17'. Agenda 21: Programme of Action for Sustainable Development and the UNCED Proceedings. New York: Oceana; Johnston, D. 1996. 'UNCLOS and UNCED: a collision of mind-sets?', in Kriwoken, L., Haward, M., VanderZwaag, D. and Davis, B. eds., Oceans Law and Policy in the Post-UNCED Era: Australian and Canadian Perspectives, London: Kluwer Law International, 15.

5 Australian Conservation Foundation (ACF) and the National Environmental Law Association (NELA). 2006. Out of the Blue: A Discussion Paper for an Australian Oceans Act. Melbourne, ACF. See Rose, G. and Smyth, C. 2006. 'Harmonising Australian environmental law: an oceans Act for Australia's oceans.’ National Environmental Law Review. 2006(1): 32-37.

6 See Vince, J.Z. 2004. The Development of Australia's Oceans Policy: Change and Stability in a Policy Community. Unpublished $\mathrm{PhD}$ thesis, Hobart, University of Tasmania; Haward, M. 1991. 'The Offshore', in B. Galligan, O. Hughes and C. Walsh, (eds) Inter-Governmental Relations and Public Policy. Sydney, Allen and Unwin; Haward, M. 2003. 'The Ocean and Marine Realm' in Dovers, S. and Wild River, S. (eds) Managing Australia's Environment. Sydney, Federation Press, pp 35-52.

7 Vince, 2003, supra note 1.

8 Ibid.

9 Ibid, at 2.

${ }^{10}$ See Commonwealth of Australia, 1997. Australia's Oceans, New Horizons, Oceans Policy Consultation Paper. Canberra, AGPS; Commonwealth of Australia, 1998. Australia's Oceans Policy - An Issues Paper, Canberra, AGPS.

${ }^{11}$ Vince, 2003, supra note 1 , at 3.

12 The Marine and Coastal Community Network (MCCN) and the Australian Committee for the World Conservation Union (ACIUCN) assisted with public consultation during 1997. See Vince, supra note 1, at 3 and ACIUCN (Australian Committee for IUCN). 1998. Conserving Australia's Oceans: Development of an Oceans Policy for Australia: Outcomes of a National Workshop. 15-17 May 1997, ACIUCN Occasional Paper Number 7, March 1998: 3.
${ }^{13}$ Vince, 2003, supra note 1 , at 3.

14 TFG International 2002. Review of the Implementation of Oceans Policy, Hobart, TFG International, 3.

${ }^{15}$ Commonwealth of Australia, 1998. Australia's Oceans Policy: Caring, Understanding and Using Wisely. Canberra, AGPS; Commonwealth of Australia, 1998b. Australia's Oceans Policy: Specific Sectoral Measures. Canberra, AGPS.

${ }^{16}$ Vince, 2003, supra note 1 , at 4.

${ }^{17}$ Commonwealth of Australia, 1998, supra note 15, at 3.

${ }^{18}$ Vince, 2003, supra note 1 , at 6.

${ }^{19}$ Ibid.

${ }^{20}$ Commonwealth of Australia, 1998, supra note 15, at 16.

21 'Environment Australia' was the Australian Government's environmental department during this time.

${ }^{22}$ Primary Industries Ministerial Council. 2007. 'About NRMMC', http://www.mincos.gov.au/about_nrmmc, last modified 23 October 2007.

${ }^{23}$ Vince, 2003, supra note 1 , at 7.

${ }^{24}$ National Oceans Office. 2003. Annual Report. Hobart: AGPS.

${ }^{25}$ Sullivan, S. 2004. 'Beyond Our Coasts - Australia's Oceans Policy', paper presented at the Coast to Coast Conference, Hobart, 19-23 April 2004.

${ }^{26}$ Vince, 2006, supra note 1 , at 428.

${ }^{27}$ TFG International 2002 Review of the Implementation of Oceans Policy, Hobart, TFG International, 1.

28 Ibid.

${ }^{29}$ See, eg, Wescott, G. 2000. 'The Development and Initial Implementation of Australia's 'Integrated and Comprehensive' Oceans Policy.' Ocean and Coastal Management. 43: 853-878.

${ }^{30}$ TFG International. 2002. Review of the Implementation of Oceans Policy, Hobart, TFG International, 2.

${ }^{31}$ Ibid, at 3.

32 Ibid.

${ }^{33}$ Ibid, at 8 .

${ }^{34}$ Ibid, at 10 .

35 Ibid.

${ }^{36}$ Ibid, at 17.

${ }^{37}$ Ibid, at 18.

${ }^{38}$ Ibid, at 19.

${ }^{39}$ See Vince, 2003, supra note 1, at 9; Vince, 2006, supra note 1 .

${ }^{40}$ Smyth, C., Prideaux, M., Davey, K. and Grady, M. 2003. Oceans Eleven, Melbourne, ACF.

${ }^{41}$ See Vince, 2003, supra note 1, at 9; Vince, 2006, supra note 1 , at 425 .

42 Smyth et al, 2003, supra note 40, at 6.

${ }^{43}$ ACF and NELA. 2004. South-East Regional Marine Plan. Media Release 18 August 2004.

${ }^{44}$ See Vince, 2006, supra note 1 , at 425.

${ }^{45}$ Vince, 2006, supra note 1, at 427.

${ }^{46}$ Foster, E., Haward M. and Coffen-Smout, S. 2005. 'Implementing Integrated Oceans Management: Australia’s South East Regional Marine Plan (SERMP) and Canada's Eastern Scotian Shelf Integrated 
Management Initiative (ESSIM).' Marine Policy. 29: 391-405; Vince, 2006, supra note 1, at 420-430.

${ }^{47}$ See Haward, M. and Vince, J.Z. (forthcoming). Oceans Governance in the Twenty-First Century: Managing the Blue Planet. United Kingdom: Edward Elgar Publishing.

${ }^{48}$ Department of the Environment, Water, Heritage and the Arts. 2008. 'Australia's Oceans Policy', http://www.environment.gov.au/coasts/oceans-policy/ index.html (viewed 10 January 2008).

${ }^{49}$ Vince, 2003, supra note 1 , at 4.

${ }^{50}$ Department of the Environment, Water, Heritage and the Arts 2008. 'Previous regional marine planning process - the South East Regional Marine Plan', http://www.environment.gov.au/coasts/mbp/south-east/ previous-process.html (viewed October 2007).

${ }^{51}$ Commonwealth of Australia, 1998, supra note 15, at 11.

52 Ibid, at 12.

${ }^{53}$ Department of the Environment, Water, Heritage and the Arts, 2008, supra note 50 .

${ }^{54}$ Department of Environment and Water Resources. 2007. 'New environment-related spending 2006-07 Budget and key recent initiatives', http://www. environment.gov.au/about/publications/budget/2006/eb o/chapter2.html (viewed 12 June 2007).

${ }^{55}$ Department of the Environment and Water Resources. 2007. 'Environment Protection and Biodiversity Act 1999', http://www.environment.gov.au/epbc/index.html (viewed 12 June 2007).

${ }^{56}$ See ACF and NELA. 2006. Out of the Blue: A Discussion Paper for an Australian Oceans Act. Melbourne, ACF; Vince J. Z. 2008. 'Policy Transfer in Oceans Governance: Learning Lessons From Australia's Oceans Policy Process'. Ocean Year Book 22: 159-181; Foster et al, 2005, supra note 46, at 391405.

${ }^{57}$ ACF and NELA, 2006, supra note 56.
58 Ibid.

${ }^{59}$ Haward, M. and Vince, J.Z. 2006. 'Australian Ocean Governance - Initiatives, Challenges and Opportunities', Australasian Political Studies Association Conference, Newcastle, 25-27 September 2006, at 9.

${ }^{60}$ See Australian Government website: http://www.australia2020.gov.au/.

${ }^{61}$ Vince, 2003, supra note 1, at 10.

${ }^{62}$ Vince, 2006, supra note 1, at 428.

${ }^{63}$ See Haward and Vince, (forthcoming), supra note 47.

${ }^{64}$ McLaughlin, M. 1987. 'Learning from Experience: Lessons from Policy Implementation'. Educational Evaluation and Policy Analysis. 9(2): 174.

${ }^{65}$ Commonwealth of Australia, 1998, supra note 15, at 3.

${ }^{66}$ Browne, A. and Wildavsky, A. 1984. 'What Should Evaluation Mean to Implementation' and 'Implementation as Mutual Adaptation' in Pressman, J. and Wildavsky, A. Implementation, 3d ed. Berkeley: University of California Press, 234.

${ }^{67}$ The Greens. 2007. 'Australian Greens Policy: Marine and Coastal Areas', http://www.greens.org.au/about/ policy (viewed March 2007).

68 Australian Labor Party. 2007. Labor's Reef Rescue Plan: Election 2007 Policy Document. October 2007.

${ }^{69}$ The Coalition Government. 2007. Election 2007 Policy: Strengthening and Protecting Australia's Fishing Industry. http://www.liberal.org.au/about/ documents/Fisheries.pdf (viewed 14 November 2007).

${ }^{70}$ Pressman, J. and Wildavsky, A. 1973. Implementation, 3d ed. Berkeley: University of California Press, 130.

${ }^{71}$ Vince, 2008, supra note 56, at 179.

${ }^{72}$ See Vince, J.Z. 2005. 'Policy Transfer in Ocean Governance: Australia, Canada and New Zealand.' Proceedings of the Australasian Political Studies Association Conference, Dunedin, New Zealand, Tasmania, September; Vince, 2008, supra note 56.

${ }^{73}$ Pressman and Wildavsky, 1973, supra note 70, at 130.

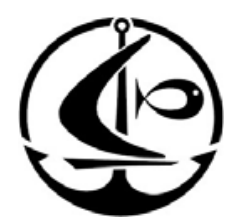

